\title{
A NEW CONCEPTUAL ORAL HEALTH LITERACY INSTRUMENT IN TURKISH: T-CMOHK
}

\author{
Kapsamlı ağız ve diş sağlığı okuryazarlığı ölçümüne \\ yönelik yeni bir araç: T-CMOHK
}

Özlem EKMEKÇi GÜNER ${ }^{1}$, Nesrin ÇíLINGIROĞLU² ${ }^{(D)}$

\begin{abstract}
Evaluating the oral health literacy $(\mathrm{OHL})$ of individuals with appropriate instruments is necessary for public dental health prevention programs. To our knowledge, there has been no comprehensive OHL instrument in Turkish up to date. This study aimed at the adaptation of the Comprehensive Measure of Oral Health Knowledge (CMOHK) to Turkish and evaluating the $\mathrm{OHL}$ of participants. The first stage of this methodological study was the cultural adaptation process with forward and back translations, cognitive interviewing, and pilot test followed by psychometric evaluation. A three-part questionnaire containing sociodemographic questions, oral health behaviors, and Turkish CMOHK (T-CMOHK) was administered among 314 volunteered students in a vocational school in Ankara, in 2019. Validity was evaluated with linguistic, content, and construct validity. Internal consistency coefficients were analyzed. $p \leq 0.05$ was considered significant. Back-translation comparisons and content validity index (1.00) were good, cognitive pre-test showed the final translation was suitable and understandable. The mean age of 307 participants included was $20.51 \pm 1.49$ with a majority of women $(62.9 \%)$. Cronbach's alpha $(0.70)$, Kuder-Richardson-20 (0.71) and split-half (0.71) coefficients were satisfactory. Of the group, $38.8 \%$ had poor; $33.9 \%$ had fair and $27.3 \%$ had good OHL (mean score $=14.21 \pm 3.49$ ). Scores were significantly higher among the participants who visited the dentist in case of a dental problem than those who did not $(\mathrm{p}=0.022)$ and who recently visited a dentist than those who never had $(p=0.007)$. T-CMOHK met the reliability and validity criteria for further research of the OHL of adults.

Keywords: Health literacy, oral health, reliability and validity, adaptation, public dental health.
\end{abstract}

\section{Özet}

Bireylerin ağız ve diş sağlığı okuryazarlığının (ADSOY) uygun araçlarla değerlendirilmesi gereklidir. Henüz Türkçe geliştirilmiş kapsamlı bir ADSOY ölçüm aracı bulunmamaktadır. Bu araştırmanın amacı "Kapsamlı Ağız ve Diş Sağığı Bilgisi Ölçüm Aracı (CMOHK)"nın Türkçeye uyarlanması ve geçerlilik ve güvenilirliğinin araştırılması, katılımcıların ADSOY düzeyinin değerlendirilmesidir. Metodolojik tipteki bu araştırmanın ilk aşamasını ileri ve geri çeviriler, bilişsel değerlendirme ve pilot denemeyi içeren kültürel adaptasyon süreci oluşturdu, sonrasında psikometrik analizler uygulandı. Sosyodemografik özellikler, ağız ve diş sağlığı ile ilgili özellikler ve T-CMOHK, olmak üzere üç bölüm içeren bir veri toplama formu, Ankara'da bulunan bir sosyal bilimler meslek yüksekokulunda kayıtlı öğrenciler içerisinde araştırmaya katılmayı kabul eden 314 öğrenciye 2019 yılı Mayıs ayı içerisinde uygulandı. Geçerlilik analizleri kapsamında dil geçerliliği, kapsam geçerliliği ve yapısal geçerlilik analizleri yapıldı. Güvenilirlik analizleri için iç tutarlılık katsayıları değerlendirildi. İstatistiksel anlamlılık değeri olarak $p \leq 0,05$ kriter alındı. Geri çeviri ve kapsam geçerliliği değerleri iyi olarak bulundu. Bilişsel geçerlilik sonuçları ölçüm aracının anlaşılabilir olduğunu gösterdi. Tam olarak doldurulmuş 307 form araştırmaya dahil edildi. Cronbach's alpha $(0,70)$, KR-20 $(0,71)$ ve iki-yarı iç tutarlılık (0.71) katsayıları yeterli olarak bulundu. Katılımcıların ADSOY düzeyleri \%38,8'nin zayıf, \%33,9'nun orta ve $\% 27,3$ 'nün iyi olarak bulundu (ortalama puan=14,21 $\pm 3,49$ ). ADSOY puanları şikayeti olduğunda hemen diş hekimine başvuranlarda başvurmayanlara göre $(p=0,022)$, ve daha önce diş hekimine gitmiş olanlarda hiç gitmemiş olanlara göre $(p=0,007)$ istatistiksel olarak anlamlı şekilde daha yüksek idi. T-CMOHK, yetişkinlerde ADSOY araştırmalarında kullanılmak üzere geçerlilik ve güvenilirlik kriterlerini karşılayan bir ölçüm aracıdır.

Anahtar kelimeler: Sağlık okuryazarlığı, ağız ve diş sağlığı, güvenilirlik ve geçerlilik, toplum ağız ve diş sağlığı.

1- Hacettepe University Vocational School of Health Sciences, Oral and Dental Clinical Assistant Program, Ankara, Turkey

2- Hacettepe University Faculty of Medicine, Public Health Department, Ankara, Turkey

Sorumlu Yazar / Corresponding Author: Dr. Dt. Özlem EKMEKÇi GÜNER (PHD)

e-posta / e-mail: ozlem.eguner@gmail.com

Geliş tarihi / Received: 15.06.2021, Kabul Tarihi / Accepted: 30.07.2021

ORCID: Özlem EKMEKÇI GÜNER : 0000-0002-5901-8374

Nesrin ÇILINNGIROĞLU : :0000-0003-4574-6829

Nasıl Atıf Yaparım / How to Cite: Ekmekçi Güner Ö, Çilingiroğlu N. A new conceptual oral health literacy instrument in Turkish: T-CMOHK. ESTUDAM Public Health Journal. 2021;6(3):216-26. 


\section{Introduction}

Due to the common risk factors that both noncommunicable diseases (NCDs) and oral health $(\mathrm{OH})$ problems share, it was emphasized that, the goals including the prevention of oral diseases and the development of oral health status (OHS), should be integrated into the global goals covering health promotion and prevention of NCDs (1). Although oral health literacy (OHL) is a remarkable potential research area, and is thought to be associated with OHS, it is still an ignored issue in Turkey. OHL, which is defined as 'the ability of individuals to obtain, process and understand basic $\mathrm{OH}$ information and services needed to make appropriate health decisions', considers the capacity of an individual for word recognition, numeracy, listening, speaking and comprehension (2). It is associated with a variety of concepts such as sex, age and education level (3-6). Previous studies have indicated the relationship between $\mathrm{OHL}$ and behaviors such as understanding and practicing dentist's instructions, dental attendance and tooth brushing frequency (7-9). In addition, other studies reported the

\section{Material-Method}

The first stage of this methodological study was the Turkish adaptation and psychometric assessment of CMOHK with classical test theory and the second stage was evaluating relationship between $\mathrm{OHL}$ and sociodemographic and $\mathrm{OH}$ behavior characteristics. The study was carried out in May 2019, among registered students in a vocational school of social sciences who accepted to participate. Validity was assessed by linguistic, content and construct validity. Internal consistency coefficients of Cronbach's alpha, Kuder-Richardson-20 (KR-20) and split-half were analyzed for the reliability evaluation and item discrimination indexes (DI) were calculated.

\section{Ethical approval}

After receiving permission from the author of CMOHK, the protocol was approved by the Ethical Committee of relationship between $\mathrm{OHL}$ and $\mathrm{OHS}$ (7, 9-11).

It is necessary to evaluate $\mathrm{OHL}$ through appropriate measurement tools in order to reveal its relationship with OHS. Although $\mathrm{OHL}$ is a remarkable research area and the number of instruments developed to assess $\mathrm{OHL}$ have increased in recent years, there still seems to be a lack of studies in Turkish. The only OHL instrument that was adapted in Turkish is the Turkish Rapid Estimate of Adult Literacy in Dentistry (T-REALD) which was designed to assess $\mathrm{OHL}$ in terms of word recognition and reading ability (12).

Comprehensive Measure of Oral Health Literacy (CMOHK) was developed (3) to evaluate the $\mathrm{OHL}$ of adults. Previous studies have been carried out by using CMOHK, but there has been no study for adaptation to Turkish yet $(3-6,10,11,13)$. This study aimed the Turkish adaptation of CMOHK and to determine the OHL of students in a vocational school while evaluating the possible relationship between $\mathrm{OHL}$ and certain characteristics.

Hacettepe University (no. 2019/10-40) in accordance with the ethical standards of the Declaration of Helsinki. Permission from the director of the school was obtained, a written informed consent was taken from each participant prior to the study.

\section{Linguistic and cultural adaptation}

The cultural adaptation process followed the recommended steps of WHO and ITC: forward translations and reconciliation; back translations and harmonization; confirmation of forward translation versus back translation by the author; and cognitive debriefing $(14,15)$. Two native Turkish academics one of whom had no prior knowledge of the instrument, made forward translations independently targeting a conceptual rather than literal equivalence. An expert panel including professionals in dentistry and public health 
came to a consensus for the final translation after resolving the discrepancies. Two translators with no prior knowledge about the instrument made the back translations to English. One of the translators had lived and worked in the USA for 15 years and the other was lecturing English lessons for more than 10 years. The final synthesized version of back translation and original items were sent to the author of CMOHK for comparison and confirmation was received that all items were acceptable and good.

\section{Cognitive interviewing}

The instrument's understandability and cultural suitability was evaluated by face-to-face cognitive debriefing interviews with a group of 30 participants who were not part of the study group but had representative sociodemographic characteristics. Participants were asked for any difficult, disturbing or unclear expressions in the content of the items and for alternative choices. A report of the process was presented to the panel of experts for further discussion.

\section{Content validity index (CVI) and pilot testing}

A judge panel of six health professionals (three dental professionals, three public health professionals) conducted 'Davis technique' to assess CVI by rating a scale from 1 to 4 points for each item (16). A three columned table comprised of forward translations, back translations and the original items was presented to the judges to be rated according to their relevance or representation by scoring as $1=i t e m$ is not clear; $2=i$ item needs major revisions to be clear, $3=$ item needs minor revisions to be clear, $4=$ item is clear. Item level CVI (I-CVI) was assessed by dividing the number of experts who rated the item as 3 or 4 , to the number of total experts. For the items rated below 4 points, recommendations were discussed and applied after consensus. CVI for the entire instrument (S-CVI) was calculated by taking the sum of I-CVIs divided by the total number of items. A pilot test with overall questionnaires was carried out with 16 volunteered participants out of the study group and the instrument was finalized as T-CMOHK.

\section{Measurement tools}

A three part-questionnaire was used for the data collection; the first two parts being on the participants' socio-demographic information and the second part on $\mathrm{OH}$ related behaviors respectively, the third questionnaire was T-CMOHK. Original $\mathrm{CMOHK}$, of which the validity and reliability were shown by previous studies, has single factorial design comprising of 23 multiple choice items with one correct $(3,5,11)$. It has four domains: a) basic $\mathrm{OH}$ knowledge; b) dental caries prevention and management; c) periodontal disease prevention and management; d) oral cancer prevention and management. In the original research, $\mathrm{OHL}$ levels were categorized as poor (0-11), fair (12-14) and good (15-23). In this study, total scores were recategorized to three levels also regarding the tertile values as poor (0-13), fair (14-16) and good (17-22).

\section{Participants and data collection procedure}

Considering the recommended sample size, which is between five to ten participants for each item, minimum number of ten participants for each item was targeted (17). Volunteers between the ages of 18-25 years who had no disability for reading and understanding of the questionnaires were included. The questionnaires were administered as self-complete forms under the researchers's supervision with no time limit and the participants were free to leave anytime they wanted. Of the 314 students accepted to participate, 307 completed questionnaires were analyzed. Final number of participants was more than 300 , which is considered as 'good' for the assessment of factor analysis (18).

\section{Reliability analysis}

Internal consistency coefficients of Cronbach's alpha, KR-20 and split-half 
values were evaluated considering values above 0.70 as acceptable (19). For DI, the items above 0.20 were considered as acceptable (20).

\section{Construct validity}

For determining the construct validity, first exploratory factor analysis (EFA) and after confirmatory factor analysis (CFA) were conducted for the factorial and item structure. Before factor analysis, Kaiser-Meyer-Olkin (KMO) test for sample adequacy and Bartlett's test of sphericity were evaluated for the suitability of the data. Since the sample size was sufficient, EFA and CFA were carried out at the same group by dividing into two subgroups (21).

Due to the single factorial structure and non-continuous dichotomous data of T-CMOHK, Unweighted Least Squares (ULS) method was applied in both EFA, CFA and item analysis with no rotation method selection. Regarding the dichotomous data, polichoric correlation method was selected for analysis. Following criterions were considered for the items consulting the field experts: low factor loading; DI value below 0.20 and an increase in Cronbach's alpha if the item is deleted. The most frequently suggested DFA model fit indices and threshold values were evaluated respectively: Chi-square/degrees of freedom

\section{Results}

\section{Cross cultural adaptation process}

Main changes with the original instrument were the change of a mouthwash brandname to only 'mouthwash' and 'American Dental Association' to 'Turkish Dental Association'. Cognitive interviews showed that the test group had difficulty to understand 'sleeping the baby with fruit juice' in Turkish culture, so 'fruit juice' was replaced with words meaning 'beverage with sugar' after consulting with a paediatric dentist. Two words for 'permanent tooth' in Turkish were used together to make the item clearer depending on the test group's suggestion. Finally, researchers agreed that all items $(x 2 / d f=1-5), \quad$ Goodness of Fit Index (GFI>0.90), Comparative Fit Index (CFI>0.90), Adjusted Goodness of Fit Index (AGFI>0.90), Normed Fit Index (NFI>0.90), Parsimonious Fit Index (PNFI>0.90), Root Mean Square $(R M R<0.08)$, Standardized Root Mean Square (SRMR<0.08), Root Mean Square of Approximation (RMSEA<0.08) (22).

\section{Statistical analysis}

Data entry was made using SPSS (Statistical Package for the Social Sciences version 23.0. IBM Corporation, Armonk, NY, USA). For the descriptive statistics, percentage; mean; standard deviation; minimum and maximum values were measured. Due to the negatively skewed score distribution of T-CMOHK, nonparametric analysis including Mann Whitney $U$ and Kruskall Wallis were used (Shapiro-Wilk test, $\quad x 2=0.088, \quad d f=307$, $\mathrm{p}<0.001$ ).

(Skewness $=-0.559$, Kurtosis $=0.481$ ). The relationship between categorical variables and test scores were evaluated by Chi-square tests. For EFA steps, Factor (version 10.8.02); for item statistics, Jmetrik (version 4.1.1) and for DFA analysis Lisrel (version 8.80) were used. Statistical analyses were carried out within $95 \%$ confidence interval with $5 \%$ significance level $(p \leq 0.05)$.

were understandable and relevant.

\section{Psychometric assessment Characteristics of the participants}

Of the 307 participants, mean age was $20.51(S D \pm 1.49)$ with the majority of women $(62.9 \%)$. More than half of the participants $(58.8 \%)$ self-reported their socioeconomic status as regular and most of them $(90.8 \%)$ had social security (Table 2 ).

\section{Validity process}

Linguistic validity results of cognitive interviewing and following pilot tests supported semantic equivalence for each 
item. Content validity for the overall S-CVI was calculated as 1.0 which represents a high degree. KMO value (0.615) and Bartlett's test of sphericity which was significant (Chi-square value $=439.9$, $p<0.001$ ) showed the data was suitable. EFA results indicated the unidimensional factorial structure. The sixth item asking about the main purpose of adding fluoride to the public drinking water' had a negative correlation and also indicated low DI. Consulting with field experts, CFA and reliability analysis were carried out with 22 items excluding the aforementioned item.

CFA results were reported as excellent for model fit of X2/df (1.26), CFI (1.00), RMR (0.013), NFI (1.00) and RMSEA (0.04) indexes. The results for GFI (0.93), SRMR (0.76) and PNFI (0.90) values were acceptable. CFA confirmed the unidimensional factorial structure extracted in EFA and no modification was suggested (Figure 1).

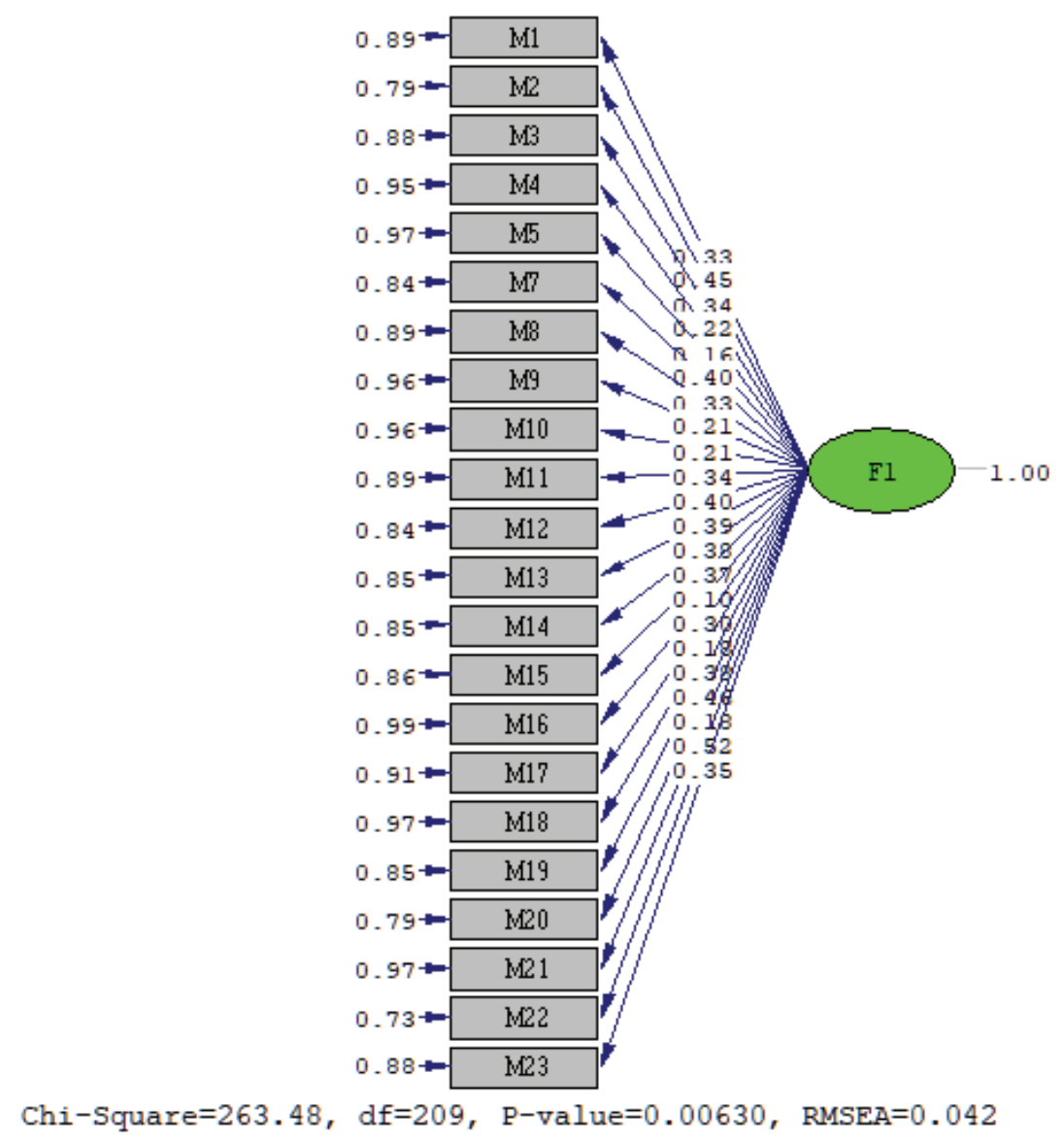

Figure 1: Standardized estimate values of CFA.

\section{Reliability analysis}

values were acceptable considering Cronbach's alpha (0.70), KR-20 (0.71) and split-half $(0.71)$. DI values for the items were between 0.17 and 0.66 while two of them were below the suggested acceptable threshold value of 0.20 (19). There was no notable increase in Cronbach's alpha with the deletion of any item (Table 1). Considering reliability and validity evaluation, $\mathrm{T}-\mathrm{CMOHK}$ met the criteria as a reliable and valid instrument for measuring the $\mathrm{OHL}$ of the target group. 
Table 1: Item analysis of T-CMOHK.

\begin{tabular}{ccccc}
\hline Item number $^{\mathrm{a}}$ & SD & $\begin{array}{c}\text { Cronbach's } \\
\text { alpha if item } \\
\text { deleted }\end{array}$ & DIF I & DI \\
\hline 1 & 0.19 & 0.69 & 0.96 & 0.66 \\
2 & 0.49 & 0.68 & 0.39 & 0.41 \\
3 & 0.40 & 0.69 & 0.80 & 0.32 \\
4 & 0.50 & 0.70 & 0.43 & 0.20 \\
5 & 0.16 & 0.69 & 0.97 & 0.45 \\
7 & 0.44 & 0.67 & 0.74 & 0.50 \\
8 & 0.50 & 0.68 & 0.52 & 0.35 \\
9 & 0.24 & 0.69 & 0.94 & 0.40 \\
10 & 0.49 & 0.69 & 0.38 & 0.24 \\
11 & 0.30 & 0.68 & 0.91 & 0.54 \\
12 & 0.43 & 0.68 & 0.75 & 0.45 \\
13 & 0.49 & 0.68 & 0.61 & 0.37 \\
14 & 0.46 & 0.68 & 0.71 & 0.35 \\
15 & 0.49 & 0.68 & 0.62 & 0.40 \\
16 & 0.47 & 0.70 & 0.68 & 0.17 \\
17 & 0.49 & 0.69 & 0.62 & 0.31 \\
18 & 0.46 & 0.69 & 0.70 & 0.25 \\
19 & 0.44 & 0.68 & 0.74 & 0.38 \\
20 & 0.44 & 0.68 & 0.74 & 0.47 \\
21 & 0.50 & 0.70 & 0.44 & 0.17 \\
22 & 0.48 & 0.67 & 0.35 & 0.52 \\
23 & 0.43 & 0.68 & 0.24 & 0.42 \\
\hline
\end{tabular}

altem number 6 was not included, SD: standard deviation.

DIF I: item difficulty index, DI: item discrimination index.

\section{Item responses}

Among the four domains, dental caries prevention and management had the highest scores (six items, $71.3 \%$ correct answers in total) and oral cancer prevention and management had the lowest (two items, $29.3 \%$ correct answers in total). General $\mathrm{OH}$ knowledge comprising nine items with a middle-high knowledge score $(68.0 \%$ correct in total) which was similar with periodontal disease prevention and management domain (five items, $64.7 \%$ correct in total). The item with the highest percentage of correct answers was the one asking the purpose of braces $(97.4 \%)$, while the item which was excluded from the study, asking for the purpose of adding fluoride to drinking water had the least $(15.0 \%)$. The item asking about the age and sex at which oral cancer is most common, had the second least correct answer $(23.8 \%)$ and had the most frequent 'I don't know' response (59.9\%).

\section{OHL scores and levels of participants}

The mean score was 14.21 $(\mathrm{SD} \pm 3.49)$ with a range of 3-21. Score range was between 8-21 for women and 3-20 for men and the mean score for women $(14.59 \pm 3.13)$ indicated a higher result than men (13.57 \pm 3.97 ) (Figure 2).

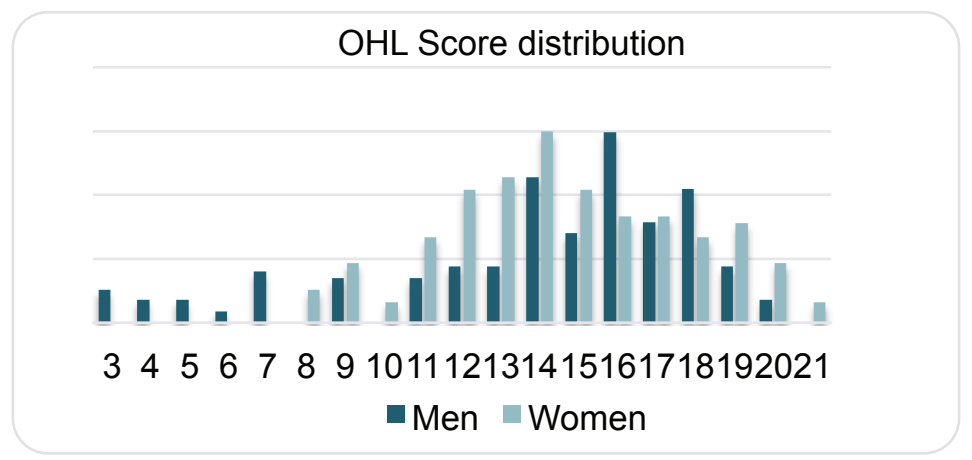

Figure 2: Distribution of OHL scores. 


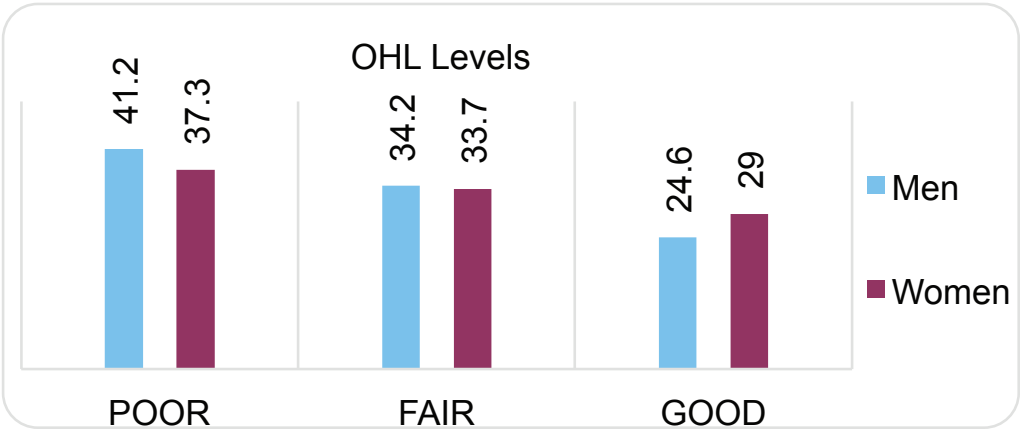

Figure 3: Percentage of OHL levels.

Of the group, $38.8 \%$ had poor, $33.9 \%$ fair and $27.3 \%$ had good OHL (Figure 3).

Both the distribution of the scores and $\mathrm{OHL}$ levels did not vary significantly according to sociodemographic characteristics (Table 2). Considering the distribution of the scores according to $\mathrm{OH}$ behaviors, the scores of participants who visit dentist in case of a dental problem were significantly higher than those who did not $(p=0.022)$. Similarly, there was a significant difference between the scores of participants who recently had dental healthcare and those who never had $(p=0.007)$. The significant difference was between the groups who received public healthcare and who never did $(p=0.002)$ and also between who received private healthcare and who never did $(p=0.006)$. Distribution of $\mathrm{OHL}$ levels did not vary significantly according to $\mathrm{OH}$ behaviors.

Table 2: Distribution of mean scores and OHL levels according to oral health behaviours.

\begin{tabular}{|c|c|c|c|c|c|c|c|c|}
\hline \multirow[b]{2}{*}{ Parameters } & \multirow[b]{2}{*}{$\begin{array}{c}\text { Total } \\
\mathrm{n}^{\mathrm{a}}(\%)^{\mathrm{b}}\end{array}$} & \multicolumn{3}{|c|}{ T-СMOHK } & \multicolumn{3}{|c|}{ T-CMOHK-OHL } & \multirow[b]{2}{*}{ p-value } \\
\hline & & $\begin{array}{r}\text { Mean } \\
(\mathrm{SD})\end{array}$ & Range & p-value & $\begin{array}{l}\text { Poor } \\
\text { n }(\%)^{c}\end{array}$ & $\begin{array}{c}\text { Fair } \\
\text { n }(\%)^{\mathrm{c}}\end{array}$ & $\begin{array}{l}\text { Good } \\
\text { n }(\%)^{c}\end{array}$ & \\
\hline \multicolumn{9}{|l|}{ Age } \\
\hline $18-19$ & $75(24.4)$ & $14.16(3.26)$ & $7-20$ & \multirow{3}{*}{$0.856^{d}$} & $31(41.3)$ & $24(32.0)$ & $20(26.7)$ & \multirow{3}{*}{0.906} \\
\hline $20-21$ & $175(57.0)$ & $14.20(3.55)$ & $3-21$ & & $65(37.1)$ & $63(36.0)$ & 47 (26.9) & \\
\hline $22-25$ & 57 (18.6) & $14.32(3.68)$ & $3-21$ & & $23(40.4)$ & $17(29.8)$ & $17(29.8)$ & \\
\hline \multicolumn{9}{|l|}{ Sex } \\
\hline Woman & 193 (37.1) & $14.59(3.13)$ & $8-21$ & \multirow[t]{2}{*}{$0.122^{\mathrm{e}}$} & 72 (37.3) & $65(33.7)$ & $56(29.0)$ & \multirow{2}{*}{0.667} \\
\hline Man & $114(62.9)$ & $13.57(3.97)$ & $3-20$ & & 47 (41.2) & $39(34.2)$ & $28(24.6)$ & \\
\hline \multicolumn{9}{|c|}{ Self-reported income } \\
\hline Poor & $13(4.3)$ & $14.62(3.49)$ & 4-20 & \multirow{4}{*}{$0.632^{d}$} & $12(63.2)$ & $4(21.1)$ & $3(15.7)$ & \multirow{4}{*}{0.503} \\
\hline Regular & 179 (58.8) & $14.19(3.45)$ & $3-21$ & & $44(37.6)$ & $40(34.2)$ & $33(28.2)$ & \\
\hline Good & 103 (33.6) & $14.53(3.19)$ & $7-21$ & & $52(36.1)$ & $51(35.4)$ & $41(28.5)$ & \\
\hline Very good & $10(3.3)$ & $12.90(3.82)$ & $3-20$ & & $11(40.7)$ & $9(33.4)$ & $7(25.9)$ & \\
\hline \multicolumn{9}{|l|}{ Social security } \\
\hline No & $28(9.2)$ & $14.00(3.82)$ & $3-20$ & \multirow[t]{2}{*}{$0.976^{e}$} & $9(32.1)$ & $13(46.4)$ & $6(21.4)$ & \multirow{2}{*}{0.344} \\
\hline Yes & $278(90.8)$ & $14.22(3.46)$ & 3-21 & & $110(39.6)$ & $91(32.7)$ & $77(27.7)$ & \\
\hline \multicolumn{9}{|l|}{ Toothbrushing } \\
\hline$\geq 2 x /$ day & $184(60.1)$ & $14.58(3.40)$ & 3-21 & \multirow{3}{*}{$0.087^{d}$} & 66 (35.9) & $60(32.6)$ & 58 (31.5) & \multirow{3}{*}{0.149} \\
\hline 1x/day & 103 (33.6) & $13.95(3.19)$ & 3-31 & & $41(39.8)$ & $40(38.8)$ & $22(21.4)$ & \\
\hline Occasionally & $19(6.3)$ & $12.58(4.75)$ & $3-20$ & & $11(57.8)$ & $4(21.1)$ & $4(21.1)$ & \\
\hline
\end{tabular}




\begin{tabular}{|c|c|c|c|c|c|c|c|c|}
\hline \multicolumn{9}{|l|}{ Dental flossing } \\
\hline Never & $191(62.6)$ & $14.07(3.42)$ & $3-21$ & \multirow{3}{*}{$0.094^{d}$} & $74(38.7)$ & $68(35.6)$ & $49(25.7)$ & \multirow{3}{*}{0.353} \\
\hline Daily & $24(7.9)$ & $13.00(4.03)$ & $3-20$ & & $12(50.0)$ & $8(33.3)$ & $4(16.7)$ & \\
\hline Occasionally & $90(29.5)$ & $14.85(3.41)$ & $4-21$ & & $31(34.4)$ & $28(31.1)$ & $31(34.4)$ & \\
\hline \multicolumn{9}{|c|}{ In case of dental problem } \\
\hline Visits dentist & $132(43.0)$ & $13.70(3.65)$ & $3-21$ & \multirow[t]{2}{*}{$0.022^{\mathrm{e}^{*}}$} & $58(43.9)$ & $44(33.4)$ & $30(22.7)$ & \multirow{2}{*}{0.06} \\
\hline Not visit & $175(57.0)$ & $14.59(3.34)$ & $3-20$ & & $61(34.9)$ & $60(34.2)$ & $54(30.9)$ & \\
\hline \multicolumn{9}{|c|}{ Last dental attendance } \\
\hline Never & $25(8.1)$ & $11.80(4.06)$ & $3-19$ & \multirow{3}{*}{$0.007^{\mathrm{d}^{*}}$} & $14(56.0)$ & $9(36.0)$ & $2(8.0)$ & \multirow{3}{*}{0.161} \\
\hline Public service & $180(58.6)$ & $14.52(3.31)$ & $3-21$ & & $67(37.2)$ & $58(32.2)$ & $55(30.6)$ & \\
\hline Private & $102(33.3)$ & $14.26(3.48)$ & $3-21$ & & $38(37.3)$ & $37(36.3)$ & $27(26.4)$ & \\
\hline \multicolumn{9}{|c|}{ Self-reported oral health } \\
\hline Very good & $19(6.2)$ & $13.21(3.41)$ & $5-21$ & \multirow[t]{4}{*}{$0.288^{d}$} & $12(63.2)$ & $4(21.1)$ & $3(15.7)$ & \multirow{4}{*}{0.503} \\
\hline Good & $117(38.1)$ & $14.49(3.28)$ & $5-20$ & & $44(37.6)$ & $40(34.2)$ & $33(28.2)$ & \\
\hline Regular & $144(46.9)$ & $14.25(3.65)$ & $3-21$ & & $52(36.1)$ & $51(35.4)$ & $41(28.5)$ & \\
\hline Poor & $27(8.8)$ & $13.52(3.63)$ & $4-18$ & & $11(40.7)$ & $9(33.4)$ & $7(25.9)$ & \\
\hline
\end{tabular}

a The total number of participants vary because of missing responses. bColumn percentages and numbers, ${ }^{c}$ Row percentages. Data is not normally distributed so non-parametric ${ }^{d}$ Kruskal-Wallis and ${ }^{~} M a n n-W h i t n e y ~ U$ tests were used. ${ }^{f}$ Chi-square. * Statistically significant. SD: standard deviation. OHL: Oral health literacy.

\section{Discussion}

In an area where majority of $\mathrm{OHL}$ instruments for adults focus on assessing word recognition and reading comprehension, this is the first study for the adaptation of a conceptual instrument to Turkish. Regarding the linguistic adaptation, the back translations of all items were confirmed to be good and cognitive interviews and pilot test showed that all the items were clear and easy to understand for the target group with no requirement for assisting the administration of the questionnaires. Content validity assessment supported the results of linguistic validity results with a high value.

It is recommended to reconsider EFA and CFA for different target groups as factorial structure and item responses may vary. $\mathrm{KMO}$ and Bartlett's tests showed that the sample was suitable so EFA and CFA analysis were conducted by dividing the group into two (21). CFA was conducted without the item which had a low DI value with a negative correlation in accordance with the field expert opinions. Two items which had DI values below suggested threshold value were not excluded since there was no notable increase in Cronbach's alpha with the deletion of any item and preservation of the integrity of the instrument was preferred (Table 1). Internal consistency coefficients of Cronbach's alpha (0.70), KR-20 (0.71) and split-half (0.71) were acceptable consistent with the previous studies conducted by $\mathrm{CMOHK}(3,5,11)$. Fit indexes were excellent for X2/df, CFI, RMR, NFI and RMSEA and acceptable for GFI, SRMR and PNFI.

The mean score was found fair (14.21 \pm 3.49$)$ with a rank of 3-21 consistent with a previous study in India where mean score was fair also (5) (Figure 2). In another study conducted in the USA (4), the majority $(61 \%)$ of the participants had insufficient $\mathrm{OH}$ scores and another study (6) resulted with a mean score which was low. Previous studies showed score ranges between 4-22 (5), 5-23 (10) and 0-22 (6). No significant difference was found considering $\mathrm{OHL}$ levels and sociodemographic characteristics, however, the mean score for women $(14.59 \pm 3.13)$ was higher (13.57 \pm 3.97$)$. When compared, there are a variety of findings in previous studies, with significant results in terms of $\operatorname{sex}(5,6)$ and some others had insignificant results $(7$, $8,10,13)$. Similar with a previous study, scores of the participants who visited dentist when they had a dental problem was 
significantly higher than those who did not $(p=0.022)$ (9). Consistent with previous studies, the mean OHL score for participants who had never visited a dentist before was significantly lower than those who had recently visited a dentist $(p=0.007)(7,9)$ (Table 2).

The majority of participants had poor $(38.8 \%)$ or fair $(33.9 \%)$ OHL where only $27.3 \%$ had good OHL. These findings were in contrast with another study (3), which, the majority of the participants had fair $(28 \%)$ or good (42\%) OHL. A study among elderly patients (10) showed $34 \%$ of the participants had poor, $27 \%$ had fair and $39 \%$ had good $\mathrm{OHL}$ while another study in India (5), reported $22 \%$ of the participants had poor, $33.7 \%$ had fair and $44 \%$ had good $\mathrm{OHL}$. Findings for the highest scores for dental caries knowledge supported the previous $(6$, $10,13)$, even so, the low scores for the item

\section{Conclusions}

The majority of participants had poor or fair OHL. The mean scores were significantly higher among participants visiting a dentist in case of a dental problem than those who did not and higher for participants who had recently visited a dentist than those who never did. asking the purpose of fluoride were in contrast with previous studies (10). Oral cancer knowledge had the lowest scores supporting the previous studies $(6,10,13)$.

Since there was no equivalent instrument in Turkish, criterion validity could not be conducted and this was one of the limitations of this study. Score distribution was negatively skewed and a normal distribution would be achieved with a larger study group. We believe that homogenous socioeconomic characteristics like age and education level caused limitation for determining the potential associations. Despite the limitations, the strengths of this study were the sample size which is considered as good for construct analysis, the results of cognitive debriefing and content validity indicating the high relevancy of the items and the acceptable consistency coefficient values revealing the reliability.

The highest score was for dental caries knowledge while the lowest was for the domain of oral cancer. This study provides contribution by a valid and reliable Turkish measurement tool in future studies for screening the OHL of adults. 


\section{References}

1. Peterson PE. Global policy for improvement of oral health in the 21st century-implications to oral health research of World Health Assembly 2007, World Health Organization. Community Dent Oral Epidemiol. 2008;37:1-8. doi:10.1111/j.1600-0528. 2008.00448.

2. National Institute of Dental and Craniofacial Research. The invisible barrier: literacy and its relationship with oral health. A report of a workgroup sponsored by NIDCR, USPHS, DHHS. Journal of Public Health Dentistry. J Public Health Dent. 2005;65(3):174-82. doi: 10.1111/j.1752-7325.2005.tb02808.

3. Macek MD, Haynes $D$, Wells $W$, Bauer-Leffler S, Cotten PA, Parker RM. Measuring conceptual health knowledge in the context of oral health literacy: preliminary results. J Public Health Dent. 2010;70(3):197-204. Available from: 10.1111/j.1752-7325.2010.00165.x.

4. Baskaradoss JK. Relationship between oral health literacy and oral health status. BMC Oral Health. 2018;18:172. doi: 10.1186/s12903-018-0640-1.

5. Jagan P, Fareed, N, Battur, H, Khanagar, $S$, Manohar, B. Conceptual knowledge of oral health among school teachers in South India. Eur J Dent. 2018; 12(1):43-8. doi: 10.4103/ejd.ejd9317.

6. Patino D, McQuistan MR, Qian F, Hernandez M, Weber-Gasparoni K, Macek MD. Oral health knowledge levels of Hispanics in lowa. J Am Dent Assoc. 2018;149(12):1038-48. http://doi.org/ 10.1016/j.adaj.2018.07.023.

7. Sabbahi DA, Lawrence HP, Limeback H, Rootman I. Development and evaluation of an oral health literacy instrument for adults. Community Dent Oral Epidemiol. 2009;37(5):451-62. doi: 10.1111/j.16000528.2009.00490.
8. Sistani MMN, Montazeri A, Yazdani R, Murtomaa $H$. New oral health literacy instrument for public health: development and pilot testing. J Investig Clin Dent. 2013;4:1-9. doi: 10.1111/jicd. 12042.

9. Ueno M, Takeuchi S, Oshiro A, Kawaguchi Y. Relationship between oral health literacy and oral health behaviors and clinical status in Japanese adults. $J$ Dent Sci. 2013;8:170-6. doi: 10.1016/ j.jds.2012.09.012.

10. McQuistan MR, Qasim A, Shao C, Straub-Morarend CL, Macek MD. Oral health knowledge among elderly patients. J Am Dent Assoc. 2015;146(1): 17-26. doi: 10.1016/j.adaj.2014.10.002.

11. Holtzman JS, Atchison KA, Macek MD, Markovic D. Oral health literacy and measures of periodontal disease. $J$ Periodontol. 2017;88(1):78-88. doi: 10.1902/jop.2016.160203.

12. Peker K, Kose TE, Guray B, Uysal O, Erdem TL. Reliability and validity of the turkish version of the rapid estimate of adult literacy in dentistry (TREALD-30). Acta Odontol Scand. 2017;75(3):198207. doi: $10.1080 / 00016357.2016 .1278079$.

13. Macek MD, Atchison KA, Watson MR, Holtzman J, Wells W, Braun B, et al. Assessing health literacy and oral health: preliminary results of a multi-site investigation. J Public Health Dent. 2016;76(4):303-13. doi:10.1111/jphd. 12156.

14. International Test Commission (2017). The ITC Guidelines for Translating and Adapting Tests (2nd ed.) www.InTestCom.org. Available from: https://www.intestcom.org/files/guideline testadaptation2ed.pdf

15. World Health Organization. Process of translation and adaptation of instruments [Internet]. 2020 [cited 2020 September 
5]. Available from: https://www.who.int/ substance_abuse/research_tools/transla tion/en/

16. Polit DF, Beck CT. The content validity index: are you sure you know what's being reported? Critique and recommendations. Res Nurs Health. 2006;29(5):489-97.

doi: 10.1002/nur. 20147.

17. Yong AG, Pearce S. A beginner's guide to factor analysis: Focusing on exploratory factor analysis. Tutor Quant Methods Pychol 2013;92(2):79-94. doi: 10.20982/tqmp.09.2.p079.

18. Pearson RH, Mundfrom DJ. Recommended sample size for conducting exploratory factor analysis on dichotomous data. J Mod Appl Stat Methods. 2010;9(2):359-68. doi: 10.22237/jmasm/1288584240.
19. Vaske JJ, Beaman J, Sponarski CC. Rethinking internal consistency in Cronbach's Alpha. Leis Sci. 2017; 39(2):163-73. doi: 10.1080/01490400. 2015.1127189.

20. Matlock-Hetzel S. Basic concepts in item and test analysis. paper presented at the annual meeting of the southwest educational research association, Austin; 1997.

21. Fabrigar LR, Wegener DT, MacCallum $R C$, Strahan EJ. Evaluating the use of exploratory factor analysis in psychological research. Psychol Methods. 1999;4:272-99. doi: 10.1037/1082-989X.4.3.272.

22. Hooper D, Coughlan J, Mullen MR. Structural equation modelling: guidelines for determining model fit. electron $j$ bus res methods. 2008;6(1):53-60. doi: 10.21427/ D7CF7R. 